Copyright (C) 2021 University of Bucharest Printed in Romania. All rights reserved

ISSN print: $1224-5984$

ISSN online: $2248-3942$
Rom Biotechnol Lett. 2021; 26(1): 2230-2235

doi: $10.25083 / \mathrm{rbl} / 26.1 / 2230.2235$

Received for publication, July, 31, 2020

Accepted, October, 8, 2020

Original paper

\title{
Experimental approaches targeting the biochemical and antioxidant potential of Synsepalum dulcificum dried fruits
}

\author{
GABRIELA POPA ${ }^{1}$, RADU TOMA ${ }^{1}$, JEAN-FRANÇOIS BOÉ ${ }^{2}$ \\ ${ }^{1}$ University of Agronomical Sciences and Veterinary Medicine, Faculty of \\ Biotechnology, Bucharest, Romania \\ ${ }^{2}$ Pierre Fabre Research Center, Pharmaceutical and dermo-cosmetic laboratories, \\ Toulouse, France
}

\begin{abstract}
This study aimed to investigate the biochemical content and antioxidant activity of methanol extracts prepared from Synsepalum dulcificum dried fruits. The results obtained by phytochemical screening of the extracts revealed the presence of some pharmacologically active chemical compounds such as: alkaloids, flavonoids, phenolic compounds and tannins. Quantitative analysis showed that the seeds had phenols in greater amounts $(157.88 \pm 2.09 \mathrm{mg} \mathrm{GAE} / \mathrm{g}$ dry matter) than dried fruit pulp $(54.09 \pm 2.24 \mathrm{mg}$ GAE / g dry matter). Contrariwise, flavonoid content was found to be low in seed $(0.013 \pm 0.02 \mathrm{mg} \mathrm{EQ} / \mathrm{g})$ and high in fruit pulp $(0.13 \pm 0.05 \mathrm{mg} \mathrm{EQ} / \mathrm{g})$. Correlated with the high amount of total phenol, in the seed extracts was found a good antioxidant activity - measured by both DPPH and ferric reducing antioxidant power (FRAP) assays. This antioxidant capacity may be also correlated with the amount of alkaloids, flavonoids, tannins and phenolic compounds, and as well as with their synergistic interactions. Synsepalum dulcificum fruits can be used as a healthy source of additives for the food industry or as natural antioxidants for the pharmaceutical industry.
\end{abstract}

Keywords Antioxidant activity, biochemical analyses, Synsepalum dulcificum dried fruits.

To cite this article: POPA G, TOMA R, BOÉ JF. Experimental approaches targeting the biochemical and antioxidant potential of Synsepalum dulcificum dried fruits. Rom Biotechnol Lett. 2021; 26(1): 2230-2235. DOI: 10.25083/rbl/26.1/2230.2235

*Corresponding author: GABRIELA POPA, University of Agronomical Sciences and Veterinary Medicine, Faculty of Biotechnology, 59 Marasti Blvd., District 1, 011464, Bucharest, Romania, Phone: +40 (21) 31822 66, Fax: +40 (21) 3182888.

E-mail: popagabiro@yahoo.com 


\section{Introduction}

Synsepalum dulcificum (miraculous fruit) is a shrub native to tropical West Africa whose fruits have a large seed that is surrounded by a thin layer of red berry flesh with a faint cherry-like flavour (G.E. INGLETT and D. CHEN [1]). The fruits have low sugar content and a slightly sweet taste. They contain a glycoprotein molecule, with several carbohydrate chains, called miraculin (K. KURIHARA and BEIDLER LM. [2]) hence the name of miraculous fruit. When the fleshy part of the fruit is ingested, this molecule binds to the taste buds of the tongue causing the sweet taste of acidic foods (G.E. INGLETT and J.F. MAY [3]. At neutral pH, miraculin binds and blocks taste receptors, but at low $\mathrm{pH}$ (resulting from ingestion of sour foods), miraculin binds proteins and becomes capable of activating sweet receptors an effect lasting up to about 30 minutes. In addition to the unique potential of fruits to make the sour taste sweet, the pigment in the red fruit peel could be a natural food ingredient (R. BUCKMIRE and F. FRANCIS [4]). Other beneficial characteristics of this fruit are the antioxidant, antibacterial and antitumor properties (T.Y. CHEN \& al [5]; L.Q. DU \& al [6]; S.L. LU \& al [7]; J. SEONG \& al [8]; S.A. STANNER \& al [9]) that are due to the different amides existing in the miraculous fruit. Apart from the above, another effect observed in this fruit was its anti-diabetic effect, which was tested in rats (C.C. CHEN \& al [10]). Medical studies have shown that it is possible to reduce and prevent the risk of chronic diseases by enhancing the natural antioxidant defense of the body or by supplementing the diet with natural antioxidants (S.A. STANNER \& al [9]; R. MARCHIOLI \& al [11]). In the last years, the medicinal properties of plants have been investigated due to their potent antioxidant activities with no side effects and economic viability (B. AUUDY \& al [12]; N.R. BHALODIA \& al [13]).

This study aimed to investigate biochemical composition (phenol compounds, flavonoids, alkaloids, and tannins) and antioxidant activities of dried fruit extracts of Synsepalum dulcificum.

\section{Materials and Methods}

\section{Plant material}

Dried fruits of Synsepalum dulcificum were purchased from the London market (UK). The fruits pulp was separated from the seeds and ground individually to a fine powder before analysis.

\section{Extraction procedure}

Each powdered sample of dried fruit pulp or seed (1g) was separately mixed with $10 \mathrm{~mL}$ methanol and stored at $250 \mathrm{C}$. After 24 hours, the mixtures were filtered and concentrated under reduced pressure in a rotary evaporator (Büchi Rotavapor R-200). The dried extracts were diluted with methanol to the concentration of $0.01 \mathrm{mg} / \mathrm{mL}$ and were used directly for analyses.

\section{Preliminary phytochemical screening}

The pulp and seed methanol extracts were screened for the presence of various compounds. Tests for alkaloids, flavonoids, phenolic compounds and tannins were carried out according to the methods described in literatures (J.B. HARBORNE [14]). For phytochemical tests between 0.5 and $1.0 \mathrm{ml}$ of each extract was used. The results were expressed based on the intensity of the color developed by the reaction and were noted with: "+++" highly present, "++" moderately present, "+" low and "-"absent.

\section{Phenolic content analysis}

Spectrophotometric determination of the total phenol content from extracts was performed according to the Folin - Ciocâlteu method (V.L. SINGLETON \& al [15]) and the absorbance measurement at $765 \mathrm{~nm}$. The total values of phenols were expressed in mg Gallic acid equivalent $(\mathrm{EAG}) / \mathrm{ml}$ sample. The measurements were obtained using an Eppendorf UV / Vis spectrophotometer. The concentration of phenols ( $\mathrm{mg}$ EAG / $\mathrm{ml}$ ) in the samples was determined based on the standard calibration curve obtained for different concentrations of Gallic acid (50-500 $\mathrm{mg} / \mathrm{ml})$. Total phenol content was determined using the formula: TPC $=\mathrm{C} \times \mathrm{DF} \times \mathrm{V} / \mathrm{M}$ (S. GOUVEIA and P. CASTILHO [16]), where: TPC - Total phenol content (mg GAE/g dry matter); $\mathrm{C}=$ the concentration determined from the calibration curve $(\mathrm{mg}$ EAG $/ \mathrm{ml})$; $\mathrm{DF}=$ dilution factor; $\mathrm{V}=$ Extraction volume $(\mathrm{ml})$; $\mathrm{M}=$ mass of plant material from extract $(\mathrm{g})$.

\section{Flavonoid content analysis}

The total flavonoid content from the extracts was determined by the colorimetric method with aluminum chloride (C. PIYANETE \& al [17]). Quercetin was used as the standard agent. For this purpose, a calibration curve for quercetin was performed. Thus, from quercetin stock solutions $(5 \mathrm{mg} / \mathrm{ml})$ were prepared methanol dilutions with different concentrations $(0.1,0.5,1.0,2.5$ and $5 \mathrm{mg} / \mathrm{ml})$. To $100 \mu \mathrm{l}$ of each quercetin methanol dilution were added sequentially: $500 \mu \mathrm{l}$ of distilled water, $100 \mu \mathrm{l}$ of $5 \%$ sodium nitrate, $150 \mu \mathrm{l}$ of $10 \%$ aluminum chloride and $200 \mathrm{ml}$ of $1 \mathrm{M}$ sodium hydroxide solution. The absorbance of this reaction mixture was measured at $510 \mathrm{~nm}$ using a UV spectrophotometer (Eppendorf UV-VIS).

Total flavonoid content in the samples was determined based on the standard calibration curve obtained for different quercetin concentrations using the formula: TFC $=\mathrm{C} \times$ DF $x$ V / M (S. GOUVEIA and P. CASTILHO [16]), where: TFC - Total flavonoid content (mg EQ / g dry matter); $\mathrm{C}=$ Quercetin concentration ( $\mathrm{mg} \mathrm{EQ} / \mathrm{ml}$ ) determined from the calibration curve; $\mathrm{DF}=$ dilution factor; $\mathrm{V}=$ Extraction volume $(\mathrm{ml}) ; \mathrm{M}=$ mass of plant material from extract $(\mathrm{g})$.

\section{Determination of antioxidant activity}

\section{DPPH radical scavenging activity assay}

DPPH (2.2-diphenyl-1-picrylhydrazyl) assay was performed according to A. BRACA \& al [18] protocol. To $200 \mu \mathrm{l}$ of each sample extract of different concentrations $(10-100 \mu \mathrm{g} / \mathrm{ml})$ were added $2 \mathrm{ml}$ of $0.004 \% \mathrm{DPPH}$ methanol $(0.1 \mathrm{mM})$ solution. After 30 minutes of incubation in the dark, at room temperature, the color change from dark purple to light yellow was determined at $517 \mathrm{~nm}$ 
compared to $1 \mathrm{ml}$ methanol (blank), using a UV spectrophotometer (Eppendorf, UV-VIS).

Different concentrations of ascorbic acid (10-200 $\mu \mathrm{g} / \mathrm{ml}$ ) were used as a standard agent. The absorbance of the DPPH solution, without extract or standard agent, was used as a control. The percentage of free radicals elimination (RSA \%) was calculated using the formula:

$$
\% R S A=\frac{\text { Abs control }- \text { Abs sample }}{\text { Abs control }} \times 100
$$

where: RSA $\%=$ Radical Scavenging Activity; Abs control = absorbance of the control solution (DPPH + methanol) and Abs sample $=$ absorbance of DPPH + sample. The dependence of the transformation percentage (RSA \%) on the concentration of the extract was plotted and the IC 50 (mg / ml) (50\% Inhibition Concentration) calculated as the concentration of the sample for which $50 \%$ inhibition of DPPH free radicals takes place.

Ferric reducing antioxidant power (FRAP) assay

The reducing power of the extracts was determined according to the method established by M. OYAIZU [19], with modifications. Thus, various concentration of test sample extracts $(10-100 \mu \mathrm{g} / \mathrm{ml})$ in $1 \mathrm{ml}$ deionized water were mixed with $2.5 \mathrm{ml}$ of phosphate buffer $(0.2 \mathrm{M}$, pH 6.6) and $2.5 \mathrm{ml}$ of $1 \%$ potassium ferricyanide [K3 $\mathrm{Fe}(\mathrm{CN}) 6]$. The mixtures were incubated at $50^{\circ} \mathrm{C}$ for 20 minutes. After incubation, the mixtures were treated with $2.5 \mathrm{ml}$ $10 \%$ tri-chloroacetic acid and centrifuged at $3000 \mathrm{rpm}$ for 10 minutes. The top layer, obtained after centrifugation, was mixed with $2.5 \mathrm{ml}$ distilled water and $0.5 \mathrm{ml}$ of $0.1 \%$ ferric chloride $(\mathrm{FeCl} 3)$. The absorbance of the solutions was measured at $700 \mathrm{~nm}$ in spectrophotometer (UV/VIS Eppendorf). Higher absorbance of the reaction mixture indicated an increased reducing power. Ascorbic acid $(800 \mu \mathrm{g} / \mathrm{ml})$ at concentrations between $10-200 \mu \mathrm{g} / \mathrm{ml}$ was used as standard agent.

\section{Statistical analysis}

All values are expressed as mean $\pm \mathrm{SD}$ of three parallel measurements. Statistical analyses were performed using Microsoft Office Excel 2010.

\section{Results and Discussions}

\section{Phytochemical screening}

The results of preliminary phytochemical screening of the extracts are shown in Table 1.

The tests revealed the presence of alkaloids, flavonoids, phenolic compounds and tannins in mostly all extracts (Figure 1).

Table1. Phytochemical profile of $S$. dulcificum pulp and seeds extracts

\begin{tabular}{|c|l|c|c|c|}
\hline Phytoconstituent & Regent/test & Color change & \multicolumn{2}{|c|}{ Presence } \\
\cline { 3 - 5 } & & & Pulp & Seed \\
\hline Alkaloids & Wagner & Reddish-brown & ++ & + \\
\hline Flavonoids & Alkaline test & Brown /yellow & ++ & + \\
\hline Phenols & Folin-Ciocalteu & Dark blue & ++ & +++ \\
\hline Tannins & Ferric chloride & Green - blue & - & +++ \\
\hline
\end{tabular}

Note: +++: highly present, ++: moderately present, +: low, -: absent

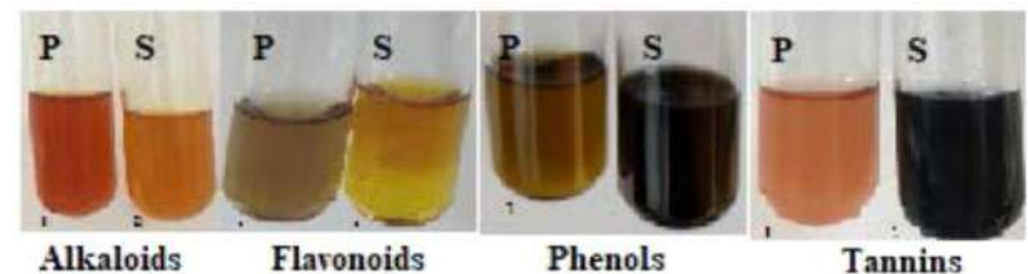

Figure 1. Presence of some chemical compounds in pulp (P) and seed (S) extracts

These phytochemical compounds are well known to have biological activities. Phytochemicals like alkaloids are low present in seed extract and moderately in pulp extract. Phenols and tannins are highly present in seed extracts. Contrariwise, in pulp extract phenols are present moderately. Also, in pulp are present a moderately content of alkaloids, flavonoids and phenols. No tannins was found in pulp extract (see Figure 1).

\section{Total phenols and flavonoids content}

Total amount of phenols were expressed in mg GAE / $g$ dry matter. Results showed that the highest amount of phenolic compounds was identified in methanol seed extracts with $157.88 \pm 2.09 \mathrm{mg} \mathrm{GAE} / \mathrm{g}$, followed by fruit pulp extracts with $54.09 \pm 2.24 \mathrm{mg} \mathrm{GAE} / \mathrm{g}$ (Table 2).

Other authors shown that skin and pulp methanol extracts of Synsepalum fresh fruits had a higher phenolic content than seed methanol extracts (G.E. INGLETT \& D. CHEN [1]). Results obtained in this study may be due to the fact that analysis was done on dried fruits, thus the pulp losing a part of the phenolic constituents during drying. Phenol compounds are considered to be potential antioxidants with ability to scavenge free radicals due to the presence of their phenolic hydroxyl groups (F. SHAHIDI \& P.K.J. WANASUNDARA [20]). 
Total flavonoid content was expressed as $\mathrm{mg}$ EQ/g dry matter (Table 2). Results showed a low flavonoid contend in both methanol extracts: $0.13 \pm 0.05 \mathrm{mg}$ EQ / g in pulp and $0.013 \pm 0.02 \mathrm{mg} E Q / \mathrm{g}$ in seed extracts. These results are consistent with those obtained by other authors who found that the skin and pulp of miracle fruit have higher flavonoid content than seeds (G.E. INGLETT \& D. CHEN [1]). Flavonoids are secondary metabolites naturally occurring in plants. Total phenolic and flavonoid contends of tested extracts are presented in Table 2.

Table 2. Phenolic and flavonoid contends of S. dulcificum in pulp and seed extracts

\begin{tabular}{|c|c|c|}
\hline Sample & $\begin{array}{c}\text { Total phenolic } \\
\text { content } \\
\text { (mg GAE/g dry } \\
\text { matter) }\end{array}$ & $\begin{array}{c}\text { Total flavonoid } \\
\text { content } \\
\text { (mg EQ/g dry } \\
\text { matter) }\end{array}$ \\
\hline Pulp extracts & $54.09 \pm 2.24$ & $0.13 \pm 0.05$ \\
\hline Seed extracts & $157.88 \pm 2.09$ & $0.013 \pm 0.02$ \\
\hline
\end{tabular}

Values represent mean $(n=3) \pm S D$.

\section{Antioxidant activities}

Antioxidants (phenols, flavonoids, alkaloids) are usually involved in several mechanisms like: inhibition of free radical generation, enhancement of scavenging capacity against free radicals, and etc. In this case, no single assay can accurately reflect antioxidant activities in a mixed products. Therefore, it is necessary to use at least two different methods to evaluate the antioxidant capacities of a product (M. ANTOLOVICH \& al [21]). In this study, two antioxidant assays, which were DPPH radical scavenging activity and ferric reducing antioxidant power (FRAP) were applied to evaluate the antioxidant properties of the methanol extracts of $S$. dulcificum seed and fruit pulp.

\section{DPPH free radical scavenging activity}

DPPH method is one of the universal tools for estimating the anti-oxidative activities of the different products (G.E. MENG \& al [22]). This method is based on the spectrophotometric measurement of DPPH concentration changes resulting from the DPPH radical reaction with an antioxidant. A suitable reducing agent donates electron / hydrogen to DPPH resulting in the colour loss of the solution, from purple to yellow. The reduction capacity of DPPH is determined by decrease in its absorbance at $517 \mathrm{~nm}$. As standard solution was used ascorbic acid $(800 \mu \mathrm{g} / \mathrm{ml})$ at different concentrations $(10-200 \mu \mathrm{g} / \mathrm{ml})$. The IC\% value of ascorbic acid was found to be 61.19. The ascorbic acid is known to have free radical scavenging activities associated with strong antioxidative activities. IC\% values of the test samples were $210.24 \mu \mathrm{g} / \mathrm{ml}$ in seed extract and $258.9 \mu \mathrm{g} / \mathrm{ml}$ in pulp extract. The RSA\% activities of the extracts are shown in Figure 2.
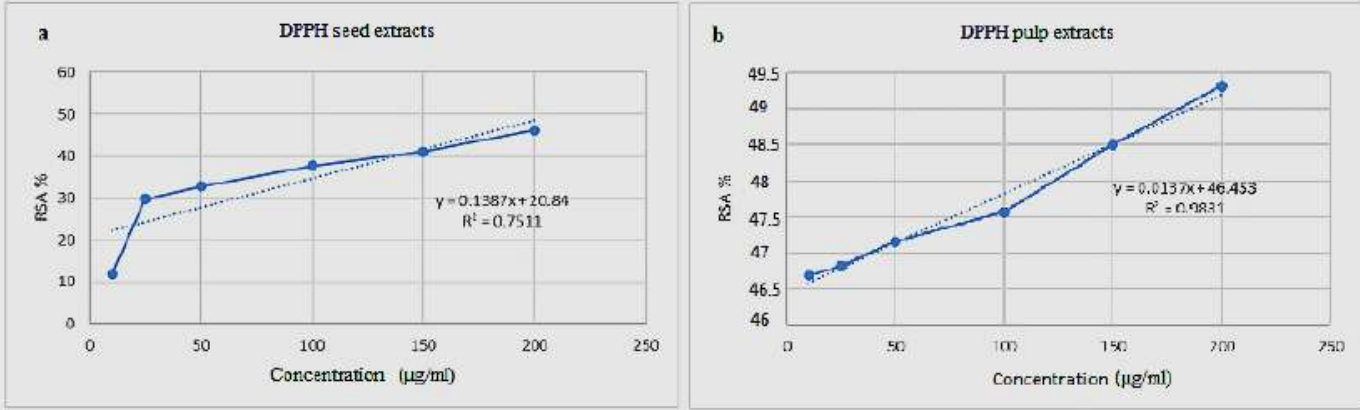

Figure 2. DPPH radical scavenging activities (RSA \%) of seed (a) and pulp extracts (b)

These data suggest that the antioxidant activity of the seed extract is higher than that of the pulp extract. These findings show that there is a correlation between a good antioxidant activity of the seed extract and the content of phenols, alkaloids, flavonoids and tannins identified in this part of the fruit. It is known that phenolic compounds are mainly responsible for antioxidant activities.

Ferric reducing antioxidant power (FRAP) activity

The total antioxidant activity of the extracts was evaluated by the ferric reducing antioxidant power assay
(FRAP). The ferric reducing capacity of extracts is based on the reaction with potassium ferricyanide $(\mathrm{Fe} 3+)$ to form potassium ferricyanide $(\mathrm{Fe} 2+)$ which than react with ferric chloride to form a complex that has a maximum absorption at $700 \mathrm{~nm}$. A higher absorbance indicates a higher reducing power of the tested samples.

Our data indicated that FRAP activity of the S. dulcificum samples increases in amount with sample concentration (Table 3). 
Table 3. Reducing power activity of methanol extracts at various concentrations

\begin{tabular}{|c|c|c|}
\hline Fruit extract & Concentration $(\boldsymbol{\mu g} / \mathbf{m l})$ & Reducing power activity (FRAP) \\
\hline Pulp & 10 & $21.20 \pm 1.14$ \\
& 20 & $42.06 \pm 1.57$ \\
& 30 & $56.44 \pm 2.99$ \\
& 40 & $75.3 \pm 2.84$ \\
& 50 & $101.08 \pm 1.42$ \\
& 100 & $160.93 \pm 1.70$ \\
\hline Seed & 10 & $44.8 \pm 1.67$ \\
& 20 & $77.39 \pm 0.53$ \\
& 30 & $86.46 \pm 2.02$ \\
& 40 & $108.26 \pm 3.92$ \\
& 50 & $124.44 \pm 2.39$ \\
& 100 & $291.36 \pm 2.06$ \\
\hline
\end{tabular}

Values represent mean $(n=3) \pm S D$

From these data we can conclude that the reducing power activity of the extracts increase depending on concentration. Among the tested samples, the seed extracts of $S$. dulcificum showed the highest reduction power activity at the same concentration. The reducing power shows a good linear relation in both standard and sample extracts (Figure 3).
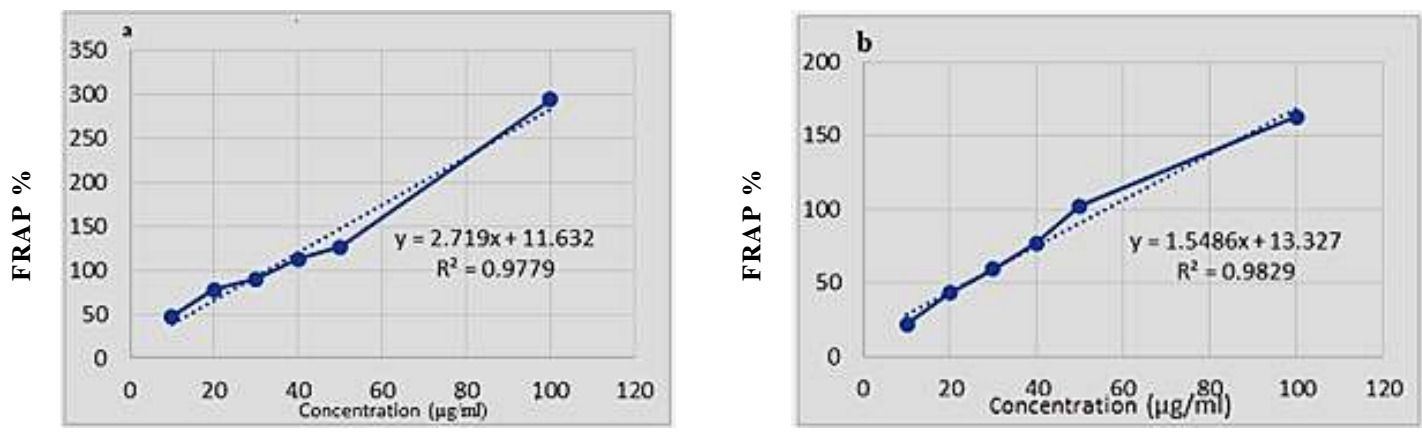

Figure 3. Ferric reducing power of seeds (a) and pulp (b) extracts

\section{Conclusions}

The results obtained in this present study suggests that antioxidant activity, investigated by DPPH and FRAP assays, was higher in seeds extract compared with the fruit pulp extract of $S$. dulcificum.

The preliminary phytochemical investigation indicated that, compared to the fruit pulp, the seeds of S. dulcificum contains phenols and tannins in high amount along with other compounds like alkaloids and flavonoids. The antioxidant activity was significantly correlated with the high amount of total phenols compounds identified in seed extracts. Results obtained in this study may be due to the fact that analysis was done on dried fruits, thus the pulp losing a part of the phenolic constituents during drying. Based on these results it is concluded that fruits of $S$. dulcificum can be used as a source of healthy additive or natural antioxidants in food or in pharmaceutical industries. Further studies need to be conducted to identify compounds in the fresh fruits of S. dulcificum, which are correlated with the antioxidant activity.

\section{References}

1. G.E. INGLETT, D. CHEN. Contents of phenolics and flavonoids and antioxidant activities in skin, pulp, and seeds of miracle fruit. J. Food Sci.; 76, C479-C482 (2011).

2. K. KURIHARA, L.M. BEIDLER. Taste-modifying protein from miracle fruit. Science; 161 (3847):1241-3 (1968).

3. G.E. INGLETT, J.F. MAY. Tropical plants with unusual taste properties. Econ Bot.; 22:326-331 (1968).

4. R. BUCKMIRE, F. FRANCIS. Anthocyanins and flavones of miracle fruit, Synsepalum dulcificum, Schum. J Food Sci.; 41:1363-1365 (1976).

5. T.Y. CHEN, Z.C. KANG, M.T. YEN, M.H. HUANG, B.S.WANG. Inhibitory effect of aqueous extracts from Miracle Fruit leaves on mutation and oxidative damage. Food Chem.; 169: 411-416 (2015).

6. L.Q. DU, Y.X. SHEN, X.M. ZHANG, W. PRINYAWIWATKUL, Z.M. XU. Antioxidant-rich phytochemicals in miracle berry (Synsepalum dulcificum) and and 
antioxidant activity of its extracts. Food Chem.; 153: 279-284 (2014).

7. S.L. LU, H. LIU, G.Y. CHEN, C.R. HAN, W.X. ZANG. Chemical composition of leaf essential oil of Synsepalum dulcificum and evaluation of its antibacterial and antitumoral activities in vitro. Chem Ind Forest Prod.; 34: 121-127 (2014).

8. J. SEONG, G.G. OYONG, E.C. CABRERA. Synsepalum dulcificum extracts exhibit cytotoxic activity on human colorectal cancer cells and upregulate c-fos and c-jun early apoptotic gene expression. Asian Pac J Trop Biomed; 8:173-8 (2018).

9. S.A. STANNER, J. HUGHES, C.N. KELLY, J. BUTTRISS. A review of the epidemiological evidence for the antioxidant hypothesis. Public Health Nutr.; 7: 407-22 (2004).

10. C.C. CHEN, I.M. LIU, J.T. CHENG. Improvement of insulin resistance by miracle fruit (Synsepalum dulcificum) in fructose-rich chow-fed rats. Phytotherapy; 20:987-992 (2006).

11. R. MARCHIOLI, C. SCHWEIGER, G. LEVANTESI, L. TAVAZZI, F. VALAGUSSA. Antioxidant vitamins and prevention of cardiovascular disease: Epidemiological and clinical trial data. Lipids; 36 (Suppl):S5363 (2001).

12. B. AUUDY, F. FERREIRA, L. BLASINA, F. LAFON, F. ARREDONDO, R. DAJAS. Screening of antioxidant activity of three Indian medicinal plants, traditionally used for the management of neurodegenerative diseases. J Ethnopharmacol; 84:131-8 (2003).

13. N.R. BHALODIA, B.N. PANKAJ, R.N. ACHARYA, V.J. SHUKLA. In vitro antioxidant activity of hydro alcoholic extract from the fruit pulp of Cassia fistula Linn. Ayu; 34(2): 209-214 (2013).
14. J.B. HARBORNE. Phytochemical methods II. Ed. In Chapman and Hall, New York; pp. 21-26 (1984).

15. V.L. SINGLETON, R. ORTHOFER, R.M. LAMUELA-RAVENTOS, P. LESTER. Analysis of total phenols and other oxidation substrates and antioxidants by means of Folin-Ciocalteu reagent. Meth. Enzymol.; 299, 152-178 (1999).

16. S. GOUVEIA, P. CASTILHO. Antioxidant potential of Artemisia argentea L'Her alcoholic extract and its relation with the phenolic composition. Food Research International; Vol. 44 (6):1620-1631 (2011).

17. C. PIYANETE, P. MEECHAI, W. NAKBANPOTEC. Sci. Antioxidant activities and phenolic contents of extracts from Salvinia molesta and Eichornia crassipes. Res J Biol.; 4:1113-1117 (2009).

18. A. BRACA, N.D. TOMMASI, L.D. BARI, C. PIZZA, M. POLITI, I. MORELLI. Antioxidant principles from Bauhinia terapotensis. J. Nat. Prod.; 64: 892-895 (2001).

19. M. OYAIZU. Studies on product of browning reaction prepared from glucose amine. Jpn J Nutr.; 44:307-15 (1986).

20. F. SHAHIDI, P.K.J. WANASUNDARA. Phenolic antioxidants. Crit Rev Food Sci Nutr.; 32:67-103 (1992).

21. M. ANTOLOVICH, P.D. PRENZLER, E. PATSALIDES, S. MCDONALD, K. ROBARDS. "Methods for testing antioxidant activity," Analyst, vol. 127, no. 1, pp. 183-198 (2002).

22. G.E. MENG, Y.C. TIAN, Y. YANG, J. SHI. Evaluation of DPPH Free Radical Scavenging Activity of Various Extracts of Ligularia fischeri In Vitro: a Case Study of Shaanxi Region. Indian J Pharm Sci.; 78(4):436-442 (2016). 